\title{
THE INDONESIAN ISLAMIC BANK'S SPIN-OFF: A STUDY IN REGIONAL DEVELOPMENT BANKS
}

\author{
Ismawati Haribowo
}

\begin{abstract}
The Indonesian Islamic Bank's Spin-Off: A Study in Regional Development Banks. The Islamic banking spin-off became a major issue after the establishment of the Act No. 21 of 2008. The problem that arises according to this spin-off is the existence of sharia unit that owned by the regional development banks, which is almost the banks has a small size. This paper is going to evaluate the spin-off criteria are regional development banks, besides that this article is going to analyze the spin-off strategy that can use by sharia unit that owned by the regional development bank. The techniques that employed in this paper are ARIMA, simulation, and descriptive-qualitative. The result shows that there is no sharia unit can achieve the 50\% share asset of its parents. There are also several strategies that can be used by the sharia unit. The main thing that should emphasize is the Islamic bank's spin-off is only one of the policies that can be taken to develop the Islamic banking industry.
\end{abstract}

Keywords: spin-off, regional development bank, ARIMA

\begin{abstract}
Abstrak. Pemisahan Bank Syariah di Indonesia: Studi Pada Bank Pembangunan Daerah. Pemisahan unit usaha syariah menjadi bank umum syariah merupakan salah satu hal yang menjadi isu utama setelah lahirnya Undang-undang nomor 21 tahun 2008. Permasalahan yang muncul terkait pemisahan unit usaha syariah ini ialah eksistensi unit usaha syariah yang dimiliki oleh Bank Pembangunan Daerah, dimana sebagian besar bank pembangunan daerah ini ukurannya kecil. Artikel ini bertujuan untuk mengevaluasi kriteria pemisahan unit usaha syariah pada Bank Pembangunan Daerah, serta untuk menganalisis strategi pemisahan yang tepat bagi unit usaha syariah yang dimiliki oleh Bank Pembangunan Daerah. Teknik analisis yang dipergunakan ialah ARIMA, simulasi, dan deskriptif-kualitatif. Hasilyang didapatkan menunjukkan bahwa belum ada satupun unit usaha syariah Bank Pembangunan Daerah yang mampu mencapai proporsi 50\% aset dari bank induknya. Terdapat beberapa strategi yang dapat ditempuh oleh unit usaha syariah Bank Pembangunan Daerah. Hal utama yang harus ditekankan ialah pemisahan unit usaha syariah merupakan salah satu kebijakan yang dapat ditempuh untuk mengembangkan industri perbankan syariah.
\end{abstract}

Kata kunci: pemisahan, bank pembangunan daerah, ARIMA 


\section{Introduction}

The Development of Islamic banking in Indonesia is quite rapid. It can see that the end of 2015 there have been 12 Islamic full pledge banks, 22 Islamic business unit, and 161 Islamic rural banks. This rapid development still has not been able to reach the market share target by 5\%; it can see from Table 1 . This 5\% target should achieve by the end of 2008. To accelerate the Islamic banking growth in Indonesia, regulators encouraged to established the particular regulation about Islamic banking industry. In 2008, there established the Act of 21 the year 2008 about Islamic banks. One important issue in this act is the obligation for Islamic business unit (UUS) to do the spin-off if they had reached the $50 \%$ of the parent's asset or 15 years after the establishment of this act. After the establishment of this act, there are several Islamic business units that had done the spin-off, either by creating new companies or by using the existing companies. If we are referring to the spin-off's criteria in the act, there are no Islamic business unit that had been reached the 50\% parent's asset. Al Arif (2015c) said that from 11 sample banks, which contained 5 Islamic business units, 4 spin-off banks, and 2 Islamic full pledge banks subsidiary of conventional banks; none of the sample banks can reach the $50 \%$ of its parent's asset in 2023 (15 years after the establishment of the act).

Table 1. The Development of Indonesian Islamic Banking Industry

\begin{tabular}{cccc}
\hline Years & $\begin{array}{r}\text { Islamic banks } \\
\text { (IDR million) }\end{array}$ & $\begin{array}{c}\text { Conventional banks } \\
\text { (IDR million) }\end{array}$ & $\begin{array}{c}\text { Market share } \\
\text { (\%) }\end{array}$ \\
\hline 2008 & 49,555 & $2,310,557$ & 2.10 \\
2009 & 66,090 & $2,534,106$ & 2.54 \\
2010 & 97,519 & $3,008,853$ & 3.14 \\
2011 & 145,467 & $3,652,832$ & 3.83 \\
2012 & 195,018 & $4,262,587$ & 4.37 \\
2013 & 229,557 & $4,954,467$ & 4.43 \\
2014 & 244,197 & $5,615,150$ & 4.18 \\
2015 & 298,382 & $5,919,390$ & 4.79 \\
\hline
\end{tabular}

Source: Islamic banking statistics, Bank of Indonesia

Table 2 shows the value of asset, share asset, and profit of Islamic business unit that owned by the regional development bank. Based on data, almost the Islamic business unit owned by regional development bank has small asset, the largest asset is Bank of DKI Shariah that can achieve IDR 3.4 trillion and the smallest asset is 
Bank of Jambi that only IDR 191 billion. This fact shows that if the spin-off policy is force to remain in the July 2023, there will be a lot of Islamic business unit owned by regional development banks will be shut-down. Because almost the parents (regional development bank) has a small economic of scale, if they forced to spin-off the Islamic business unit it will make the inefficiency either in parents or subsidiary banks.

The Islamic banking data shows that after the spin-off policy established in 2008, there are still performance fluctuations in Islamic banking industry. This is shown by the decreasing in Islamic banking profitability, and the increasing of non performing financing. This fact is contradicst with the policy objectives. The objectives of the spin off policy is to increase the Islamic banking performance, but the data shows that there are a performance declining in Islamic banking industry.

Table 2. The Asset, Share Asset and Profit of Sharia Unit

\begin{tabular}{clccc}
\hline & \multicolumn{1}{c}{ Banks } & $\begin{array}{c}\text { Asset } \\
\text { (million rupiah) }\end{array}$ & $\begin{array}{c}\text { Share asset } \\
(\%)\end{array}$ & $\begin{array}{c}\text { Profit } \\
\text { (million rupiah) }\end{array}$ \\
\hline 1 & UUS DKI & $3,384,929$ & 9.29 & 103,382 \\
2 & UUS Sumut & $1,816,290$ & 7.77 & 79,125 \\
3 & UUS BPD Yogyakarta & 366,694 & 4.69 & 12,322 \\
4 & UUS BPD Jateng & 960,654 & 2.28 & 5,042 \\
5 & UUS BPD Jatim & $1,247,248$ & 3.28 & 11,715 \\
6 & UUS BPD Jambi & 191,582 & 3.31 & 9,632 \\
7 & UUS BPD Aceh & $2,408,925$ & 12.77 & 49,861 \\
8 & UUS BPD Sumbar & $1,224,605$ & 6.80 & 35,251 \\
9 & UUS BPD Riau & $1,013,781$ & 4.43 & 37,249 \\
10 & UUS Sumsel & $1,021,885$ & 6.36 & 11,988 \\
11 & UUS Kalsel & 588,010 & 5.43 & 8,517 \\
12 & UUS Kalbar & $1,199,564$ & 10.69 & 74,127 \\
13 & UUS Kaltim & $1,110,263$ & 3.74 & 14,108 \\
14 & UUS Sulselbar & 724,954 & 7.25 & 42,612 \\
15 & UUS NTB & 383,027 & 6.60 & 9,547 \\
\hline
\end{tabular}

Source: Bank's Publication Report

Besides that, Novarini (2009), Pramuka (2011), and Endri (2011) shows that almost the Islamic business unit is less efficient rather than Islamic full pledge 
banks. This result raise question if Islamic buisness unit is less efficient than Islamic full pledge banks, how about the efficiency if they had done the spin-off. Al Arif (2015a) shows that the spin-off policy will affect the performance in Islamic banking industry. There is an efficiency declining after the spin-off policy established.

According to the conditions, which is the spin-off policy still can't give a significant effect to the Islamic banking industry development. Besides that, this policy still can't accelerate the Islamic banking industry to achieve the 5\% share asset. This research will analyze the spin-off strategy in Islamic business unit that owned by the regional development banks. Besides that, the regulator such as the financial service authority has a concern about spin-off policy in regional development banks.

\section{Literature Review}

Only a few numbers of research had been conducted regarding the Islamic banking spin-off, because the characteristics of Islamic banking in Indonesia are quite different than Islamic banking in other countries. Indonesia splits Islamic bank into two parts; Islamic banks and Islamic business unit (an Islamic business units of conventional banks), while in other countries mostly use windows system that gives no differences between Islamic banks and conventional banks. In order to reach the Islamic banking market share $5 \%$ of the national banking, one method used is to push the occurrence of Islamic business unit spin-off into Islamic fullpledge banks. The effort to push this spin-off is seen on several policies of Bank Indonesia such as PBI No. 12/21/PBI/2010 date October $19^{\text {th }} 2010$ regarding Bank's Business Plan, especially on article 12 letter $g$ that puts the Islamic business unit spin-off plan into the bank's business plan. PBI No. 14/8/PBI/2012, date July $13^{\text {th }} 2012$ regarding Bank Ownership of Common Shares, especially on article 16 that gives leeway for BUS shareholders as a result of Islamic business unit spin-off to have shares exceeding the maximum limit of shareholding. Islamic banks as a result of the spin-off is given a longer spare time to carry out divestment until 2028 or 5 years longer than the spin-off's time limit.

Kiswono (2012) conducted a study toward spin-off roadmap arranged by Islamic business unit. Based on a conducted study, it can be concluded that the spin-off plan submitted by each bank cannot always be used as reference. There are only few banks whose spin-off plans are reasonable enough to come to realization. Some other banks look very optimistic in planning the time of the spin-off, but if looking at its potential, it is too difficult to be held, and on the contrary, there are some banks that look very conservative in planning the spin-off to reach the limit although its capital is adequate. 
Kiswono (2012) categorized each bank based on its capital potential, namely: (i) primary capital is above IDR 2 trillion and Islamic business unit capital is above IDR 500 billion, so its capital requirement has met in provision and is hoped to be able to execute the Islamic business unit spin-off immediately. Banks included in this group are BTN, Bank Permata, CIMB Niaga, and Bank Danamon. (ii) primary capital is above IDR 2 trillion but Islamic business unit capital is still below IDR 500 billion, so it still needs longer time and effort to increase its Islamic business unit capital to reach minimum requirement that is IDR 500 billion. There are 5 banks that have fulfilled the criteria, namely: BII, BTPN, OCBC-NISP, HSBC, Bank Jatim. (iii) primary capital is still below IDR 2 trillion but more than IDR 1 trillion, so it still needs more effort because it needs to increase its primary capital to reach IDR 2 trillion, as well as increasing its Islamic business unit capital. Banks included in this category are: BPD Jateng, BPD Banda Aceh, BPD Sumt, Bank DKI, Bank Sinarmas, BPD Riau, BPD Sumsel \& Babel, BPD Sumbar, and BPD Jambi. (iv) primary capital is below IDR 1 trillion, so it is quite difficult to fulfill the obligation of executing spin-off. Banks included in this category are BPD Kaltim, BPD Kalsel, BPD Kalbar, BPD Sulsel, BPD NTB and BPD DIY.

According to Kiswono (2012), there are some strategies that can be performed regarding the matters above. First, conducting a pure Islamic business unit spinoff into Islamic full-pledge banks; Second, joining other banks; Third, performing acquisition toward conventional banks, then performing conversion on banks that have been acquired as Islamic banks; Fourth, performing conversion on parent conventional banks into Islamic banks.

Nasuha (2012) shows that there are differences in performance between before and after spin-off is executed on 3 variables such as Assets, Financing, and Third party funds (DPK) whereas on variable CAR, FDR, ROA, and ROE does not show any difference in performance between a year before and after the spin-off. Rizqullah (2013) found that the Islamic business unit spin-off method by forming a new committee/corporation is the most suitable alternative in establishing Islamic Banks. The next strategic alternative choice is a spin-off with using an already formed committee/corporation. Both of the spin-off methods are influenced by different kinds of elements. Spin-off method with forming new committee is mostly influenced by these elements: corporation's culture, communication program, customers' response, delivery channel, competitors' response, and taxes. Spin-off method with already formed committee is mostly influenced by these elements: employee's status transfer, reporting and recording system, IT system, taxes, regulators' response and due diligence. These elements differences show that the problem's priority on both methods is also different. 
According to Rizqullah (2013), these are factors that need to be taken into account on spin-off process: First, the company should appoint leadership and strong and solid spin-off teamwork project as well as being capable of carrying out their duties on time. Second, the implementation stage that includes consideration agreement or strategic reason and comprehensive spin-off plan including capital agreement and investor's identification to strengthen business plan arrangement after spin-off must be executed well as guidance for spin-off team. Roles and involvement of conventional parent banks at this stage is very crucial because it shows commitment and support to its Islamic business unit spin-off. Third, the spin-off implementation stage that includes the forming of organization of Islamic bank, integration program and legal process are the actual spin-off process. Fourth, technology and infrastructure that includes information and technology system, recording and reporting as well as delivery channel must be prepared well. Fifth, officialdom that includes officialdom status change and company cultural change must acquire serious attention in spin-off process. Sixth, the company also needs to pay attention to how the customers' response about the spin-off. The existence of Islamic bank spin-off is hoped to be supported by citizens by staying as customers.

Siswantoro (2014), in his article, analyzed performance and strategy Islamic banks after spin-off and come up as commercial banks separated from their parent banks. The result of the analysis showed that Islamic banks as the result of spin-off should be able to optimize several funding resources such as capital injections and temporary investment deposit increase. Al Arif (2014) showed that spin-off policy gives different influence toward DPK to Islamic banking industry before and after the spin-off. Similar result had been acquired by Al Arif (2015) that showed spin-off policy does not give any difference in the amount of the distribution of funding on Islamic banks as the result of spin-off between before and after the spin-off is executed.

Hamid (2015) conducted a study that aimed to seek the impact of spinoff policy toward the level of profitability on Islamic banking industry. Variable used is ROA ratio to measure the level of profitability, while the independent variable is dummy spin-off variable, levels of funding problems (NPF), the level of margin deposits 1 month, and efficiency level (BOPO). The result showed that dummy spin-off variables, NPF ratio, and BOPO ratio have influence toward the level of profitability (ROA). Al Arif (2015) showed that spin-off policy that had been executed gives difference to efficiency level on Islamic banking industry. The result shows that spin-off policy increases BOPO ratio on Islamic banking industry, where this means that level of operational efficiency from Islamic banking industry decreases after the spin-off policy is executed.

There are three approaches in forming Islamic bank, namely: first, conventional 
banks execute spin-off on Islamic business unit owned, then the Islamic business unit becomes Islamic full pledge bank (BUS) -this matter is known as pure spin-off-, such as Bank of BNI Sharia and Bank of Jabar Banten Sharia. Second, conventional banks that possess Islamic business unit acquire relatively small banks and later convert them into sharia and separate them as well as joining their Islamic business unit with recently converted banks. Islamic full-pledge banks (BUS) from first approach are: Bank of BRI Sharia, Bank of Bukopin Sharia, Bank of BTPN Sharia. Third, conventional banks that have yet to possess Islamic business unit, acquire relatively small banks and convert them into sharia and later separate them from conventional parent banks. Islamic banks (BUS) from second approach are: Bank of Panin Sharia, Bank of Victoria Sharia, Bank of BCA Sharia, and Maybank Sharia.

\section{Methods}

This paper attempts to predict the growth of the Indonesian Islamic banks, particularly to examine whether the Islamic banks of 50\% share asset that can be achieved by the Islamic banks. The econometrics tool that used to make the prediction is Autoregressive Integrated Moving Average (ARIMA). This tool is used to estimates whether the $50 \%$ share asset can be achieved in the year 2023 . The variable that is going to predict is the share asset of Islamic banking units from their conventional parent banks. The research objects of this research are thirteen sharia units namely Bank of Sumatera Utara, Bank of Sumatera Barat, Bank of Riau and Kepri, Bank of Sumatera Selatan and Bangka Belitung, Bank of Yogyakarta, Bank of DKI, Bank of Jawa Timur, Bank of Jawa Tengah, Bank of Kalimantan Timur, Bank of Kalimantan Barat, Bank of Kalimantan Selatan, Bank of Nusa Tenggara Barat, and Bank of Sulawesi Selatan and Barat.

Besides that, this research is also using the descriptive analysis by doing the in-depth interview with the regulators and the bankers. The descriptive analysis is used to support the empirical result of ARIMA. A simulation to predict the asset growth per year that to be achieved by all sample banks if they want to achieve $50 \%$ of share asset from their parents is also used in this research. The simulation is using the compound growth assumption.

\section{Result and Discussion}

\section{Result}

The first stage in the ARIMA process is the stationary test by using the unit root test. The unit root test is using the Augmented Dickey-Fuller. The first test was carried out at the level; if it is not stationary in a stationary level, it will be tested 
at the level of the first difference. The test results with test ADF at sample banks showed that the data has been stationary at the current level. After the stationary test is done, we can proceed to the next step.

Then, the correlogram will be seen. First, the correlogram of the AutoCorrelation (AC) function will be seen. The lag for Moving Average (MA) model will be got. Next, the correlogram will be seen for the partial auto-correlation (PAC) function. The optimum lag for auto-regressive (AR) model will be got. To get the best model is based on the goodness of fit from the model by using the Akaike Information Criterion (AIC) and Schwarz Criterion (SC). After the goodness of fit of the model is done, next the ARIMA for prediction is used according to the purpose of this research.

Table 3. The Lag of AR and MA Process

\begin{tabular}{clcccc}
\hline No. & \multicolumn{1}{c}{ Bank } & AR & Stationary & MA & ARIMA \\
\hline 1 & UUS BPD Sumut & 1 & Level & 4 & $(1,0,4)$ \\
2 & UUS BPD SumBar & 1 & Level & 0 & $(1,0,0)$ \\
3 & UUS BPD Sumsel \& Babel & 0 & Level & 2 & $(0,0,2)$ \\
4 & UUS BPD Riau \& Kepri & 0 & Level & 1 & $(0,0,1)$ \\
5 & UUS BPD Yogyakarta & 2 & Level & 2 & $(2,0,2)$ \\
6 & UUS BPD DKI & 0 & Level & 1 & $(0,0,1)$ \\
7 & UUS BPD Jawa Timur & 3 & Level & 2 & $(3,0,2)$ \\
8 & UUS BPD Jawa Tengah & 1 & Level & 1 & $(1,0,1)$ \\
9 & UUS BPD KalBar & 3 & Level & 1 & $(3,0,1)$ \\
10 & UUS BPD KalSel & 4 & Level & 3 & $(4,0,3)$ \\
11 & UUS BPD KalTim & 1 & Level & 4 & $(1,0,4)$ \\
12 & UUS BPD NTB & 4 & Level & 0 & $(4,0,0)$ \\
13 & UUS BPD Sulselbar & 2 & Level & 0 & $(2,0,0)$ \\
\hline
\end{tabular}

Next, a simple simulation by using multiple growths is done. From Table 5 it is showed that if the Islamic banks want to achieve the $50 \%$ of share asset from the parent banks, then they must have an asset growth approximately 37\% every year (with 5\% assumption of parent banks) and must have an asset growth approximately $43.38 \%$ every year (with $10 \%$ assumption of parent banks). The highest annual growth target is Bank of Jawa Tengah and the lowest annual growth target is Bank of Kalimantan Barat. However this growth target is hard to be achieved because of the fact that the average growth of the parent banks is larger than $10 \%$ every year. 
Table 4. Summary of Share Asset

\begin{tabular}{clcc}
\hline No. & \multicolumn{1}{c}{ Bank } & Current Year (2015) & Predicted Value (2023) \\
\hline 1 & UUS BPD Sumut & $7.88 \%$ & $10.16 \%$ \\
2 & UUS BPD SumBar & $6.55 \%$ & $15.03 \%$ \\
3 & UUS BPD Sumsel \& Babel & $7.08 \%$ & $12.33 \%$ \\
4 & UUS BPD Riau \& Kepri & $5.21 \%$ & $6.55 \%$ \\
5 & UUS BPD Yogyakarta & $5.74 \%$ & $7.76 \%$ \\
6 & UUS BPD DKI & $8.96 \%$ & $11.99 \%$ \\
7 & UUS BPD Jawa Timur & $3.95 \%$ & $12.12 \%$ \\
8 & UUS BPD Jawa Tengah & $3.26 \%$ & $8.10 \%$ \\
9 & UUS BPD KalBar & $10.04 \%$ & $14.54 \%$ \\
10 & UUS BPD KalSel & $5.63 \%$ & $6.53 \%$ \\
11 & UUS BPD KalTim & $6.04 \%$ & $7.65 \%$ \\
12 & UUS BPD NTB & $8.27 \%$ & $12.10 \%$ \\
13 & UUS BPD Sulselbar & $4.73 \%$ & $6.28 \%$ \\
\hline
\end{tabular}

Besides that, a simple simulation had done for deposit funds. Table 6 show that if the Islamic banks want to achieve the $50 \%$ of share deposit funds from the parent banks, then they must have an asset growth approximately $39.65 \%$ every year (with 5\% assumption of parent banks) and must have an asset growth approximately $46.38 \%$ every year (with $10 \%$ assumption of parent banks). The highest annual growth target is Bank of Jawa Tengah and the lowest annual growth target is Bank of Sumatera Utara. However this growth target is hard to be achieved because of the fact that the average growth of the parent banks is larger than $10 \%$ every year.

\section{Discussion}

The result on previous part showed that none of the Islamic business units can fulfill the criteria for the proportion of assets 50\% from the conventional parent bank in 2023. This issue showed that the rules for the spin-off of Islamic business unit into Islamic banks in the form of achievement of $50 \%$ proportion of assets from the parent bank must evaluate. This result is similar to what Al Arif had done (2016) with using 11 bank samples that consist of 5 Islamic business units, 4 Islamic banks that had separated after the constitution, and 2 Islamic banks that had separated before the constitution.

$\mathrm{Al}$ Arif (2016) showed that the criteria of the asset value of Islamic business unit toward the conventional parent bank have some weaknesses as follows. First, 
Al-Iqtishad: Jurnal Ilmu Ekonomi Syariah (Journal of Islamic Economics) Vol. 9 (1), January 2017

asset growth happens whether in Islamic business unit or conventional parent bank, so that it would be difficult for an Islamic business unit to reach a value $50 \%$ asset from its parent bank. Islamic business unit must gain asset growth larger than the conventional parent bank, but if Islamic business unit chases too much growth, it will cause bad impact in the long term.

Table 5. Simulation Result of Asset

\begin{tabular}{|c|c|c|c|c|}
\hline No & & $\begin{array}{l}\text { Growth Assumption } \\
\text { of Islamic Banks }\end{array}$ & $\begin{array}{l}\text { Growth Assumption of } \\
\text { Parent's Banks }\end{array}$ & $\begin{array}{c}\text { Estimation of } \\
\text { Share Asset }\end{array}$ \\
\hline \multirow{2}{*}{1} & \multirow{2}{*}{ UUS BPD SuMut } & $32.5 \%$ & $5.0 \%$ & $50.69 \%$ \\
\hline & & $39.0 \%$ & $10.0 \%$ & $51.25 \%$ \\
\hline \multirow{2}{*}{2} & \multirow{2}{*}{ UUS BPD Sum Bar } & $35.5 \%$ & $5.0 \%$ & $50.42 \%$ \\
\hline & & $42.0 \%$ & $10.0 \%$ & $50.55 \%$ \\
\hline \multirow{2}{*}{3} & \multirow{2}{*}{$\begin{array}{l}\text { UUS BPD SumSel } \\
\& \text { Babel }\end{array}$} & $35.0 \%$ & $5.0 \%$ & $51.33 \%$ \\
\hline & & $40.5 \%$ & $10.0 \%$ & $50.17 \%$ \\
\hline \multirow{2}{*}{4} & \multirow{2}{*}{$\begin{array}{l}\text { UUS BPD Riau } \\
\text { Kepri }\end{array}$} & $39.5 \%$ & $5.0 \%$ & $50.52 \%$ \\
\hline & & $46.0 \%$ & $10.0 \%$ & $50.12 \%$ \\
\hline \multirow{2}{*}{5} & \multirow{2}{*}{$\begin{array}{l}\text { UUS BPD } \\
\text { Yogyakarta }\end{array}$} & $38.0 \%$ & $5.0 \%$ & $51.09 \%$ \\
\hline & & $44.5 \%$ & $10.0 \%$ & $50.89 \%$ \\
\hline \multirow{2}{*}{6} & \multirow{2}{*}{ UUS BPD DKI } & $30.5 \%$ & $5.0 \%$ & $51.03 \%$ \\
\hline & & $36.5 \%$ & $10.0 \%$ & $50.39 \%$ \\
\hline \multirow{2}{*}{7} & \multirow{2}{*}{ UUS BPD JaTim } & $45.0 \%$ & $5.0 \%$ & $50.83 \%$ \\
\hline & & $51.5 \%$ & $10.0 \%$ & $51.15 \%$ \\
\hline \multirow{2}{*}{8} & \multirow{2}{*}{ UUS BPD JaTeng } & $48.0 \%$ & $5.0 \%$ & $50.85 \%$ \\
\hline & & $55.0 \%$ & $10.0 \%$ & $50.72 \%$ \\
\hline \multirow{2}{*}{9} & \multirow{2}{*}{ UUS BPD KalBar } & $29.0 \%$ & $5.0 \%$ & $50.52 \%$ \\
\hline & & $34.5 \%$ & $10.0 \%$ & $50.16 \%$ \\
\hline \multirow{2}{*}{10} & \multirow{2}{*}{ UUS BPD KalSel } & $38.0 \%$ & $5.0 \%$ & $50.09 \%$ \\
\hline & & $45.0 \%$ & $10.0 \%$ & $51.29 \%$ \\
\hline \multirow{2}{*}{11} & \multirow{2}{*}{ UUS BPD KalTim } & $37.0 \%$ & $5.0 \%$ & $50.76 \%$ \\
\hline & & $43.5 \%$ & $10.0 \%$ & $50.69 \%$ \\
\hline \multirow{2}{*}{12} & \multirow{2}{*}{ UUS BPD NTB } & $32.0 \%$ & $5.0 \%$ & $50.06 \%$ \\
\hline & & $38.0 \%$ & $10.0 \%$ & $50.75 \%$ \\
\hline \multirow{2}{*}{13} & \multirow{2}{*}{ UUS BPD SulSelBar } & $41.0 \%$ & $5.0 \%$ & $50.00 \%$ \\
\hline & & $48.0 \%$ & $10.0 \%$ & $50.78 \%$ \\
\hline
\end{tabular}


Second, prudential aspects in the distribution of funding must take into account. Islamic business unit which conducts accelerated growth of market share asset would try to increase the allocation of funding. To chase big asset growth would make relevant Islamic bank to improve the distribution of funding, distribution of funding who lacks prudential aspects would cause the increase of financing problems. Third, comparison of the value of assets between Islamic business unit and conventional parent bank is a related matter, so it cannot compare to Islamic business unit and a sharia subsidiary of a large conventional bank with the relatively small conventional bank. Fourth, asset share value does not have any direct connection with the net profit from relevant Islamic bank. If we look at the data, it is seen that Bank of CIMB Niaga whose asset share values is 3.73\% able to earn current year profit for IDR 104 billion, where this amount of gain is similar with the net profit of Bank of DKI for IDR 104 billion, but it has shared asset for $9.29 \%$. Therefore, factors of the current year profit for the last several years can include as one of the spin-off requirements compared to the asset share value Islamic Business Unit with its conventional parent bank.

The requirements or criteria of the Islamic business unit spin-off into Islamic bank must undergo a strict process (Al Arif, 2016): First, capital aspect is one of the major concerns because it has a close connection with market segments chosen by BUS as the result of the spin-off. It is better that capital requirement for the split bank returned by rules of the establishment of Islamic banks that apply, which is 1 trillion Rupiahs. This matter is intended so that Islamic banks as the result of spin-off would be vigorous and independent after the spin-off. Besides that, it also aimed so that Islamic banks as the result of spin-off would be able to get into BUKU 2 whose banking activities are more than BUKU 1 where the initial capital is below 1 trillion. Second, the Islamic business unit asset to do the spin-off process. For example, an interview from one of the branch head of CIMB Niaga Syariah states that Islamic business unit will execute spin-off of the asset value reaches IDR 20 trillion. Similar things also done by Bank of BTN who targets that spin-off will be performed if the asset of Islamic business unit reaches IDR 20 trillion. Third, the aspect of financial performance of relevant business units. For example, the amount of profit achievement, the level of efficiency, the ratio of financing problems or any other indicators of appropriate Islamic business unit during the last three to five years. A company who has good performance before the spin-off will have a tendency to have a better performance after the spin-off. Fourth, owner's commitment toward the development of Islamic banking industry is required. The form of duties are (a) Putting a business plan of sharia subsidiary into parent bank's business plan. (b) Putting aspects of Islamic services as one of the indicators of important performance of employees in the parent bank. (c) Preparing the infrastructure of the sharia subsidiary before the spin-off, one of them by adjusting 
Al-Iqtishad: Jurnal Ilmu Ekonomi Syariah (Journal of Islamic Economics) Vol. 9 (1), January 2017

offices services in regions that have real business potential; (d) developing the best human resources to lead BUS as the result of the spin-off.

Table 6. Simulation Result of Deposit Funds

\begin{tabular}{|c|c|c|c|c|}
\hline No & & $\begin{array}{l}\text { Growth Assumption } \\
\text { of Islamic Banks }\end{array}$ & $\begin{array}{c}\text { Growth Assumption } \\
\text { of Parent's Banks }\end{array}$ & $\begin{array}{l}\text { Estimation of Share } \\
\text { Deposit Funds }\end{array}$ \\
\hline \multirow{2}{*}{1} & \multirow{2}{*}{ UUS BPD SuMut } & $30.50 \%$ & $5.0 \%$ & $50.86 \%$ \\
\hline & & $36.50 \%$ & $10.0 \%$ & $50.22 \%$ \\
\hline \multirow{2}{*}{2} & \multirow{2}{*}{ UUS BPD Sum Bar } & $42.50 \%$ & $5.0 \%$ & $50.28 \%$ \\
\hline & & $49.50 \%$ & $10.0 \%$ & $50.86 \%$ \\
\hline \multirow{2}{*}{3} & \multirow{2}{*}{$\begin{array}{l}\text { UUS BPD SumSel \& } \\
\text { Babel }\end{array}$} & $32.00 \%$ & $5.0 \%$ & $50.60 \%$ \\
\hline & & $38.50 \%$ & $10.0 \%$ & $51.23 \%$ \\
\hline \multirow{2}{*}{4} & \multirow{2}{*}{ UUS BPD Riau Kepri } & $35.50 \%$ & $5.0 \%$ & $50.20 \%$ \\
\hline & & $42.00 \%$ & $10.0 \%$ & $50.33 \%$ \\
\hline \multirow{2}{*}{5} & \multirow{2}{*}{ UUS BPD Yogyakarta } & $42.00 \%$ & $5.0 \%$ & $50.33 \%$ \\
\hline & & $49.00 \%$ & $10.0 \%$ & $50.98 \%$ \\
\hline \multirow{2}{*}{6} & \multirow{2}{*}{ UUS BPD DKI } & $33.00 \%$ & $5.0 \%$ & $50.44 \%$ \\
\hline & & $39.50 \%$ & $10.0 \%$ & $50.92 \%$ \\
\hline \multirow{2}{*}{7} & \multirow{2}{*}{ UUS BPD JaTim } & $44.00 \%$ & $5.0 \%$ & $50.89 \%$ \\
\hline & & $51.00 \%$ & $10.0 \%$ & $51.28 \%$ \\
\hline \multirow{2}{*}{8} & \multirow{2}{*}{ UUS BPD JaTeng } & $53.50 \%$ & $5.0 \%$ & $50.31 \%$ \\
\hline & & $61.00 \%$ & $10.0 \%$ & $50.79 \%$ \\
\hline \multirow{2}{*}{9} & \multirow{2}{*}{ UUS BPD KalBar } & $43.50 \%$ & $5.0 \%$ & $50.08 \%$ \\
\hline & & $50.50 \%$ & $10.0 \%$ & $50.52 \%$ \\
\hline \multirow{2}{*}{10} & \multirow{2}{*}{ UUS BPD KalSel } & $39.00 \%$ & $5.0 \%$ & $50.41 \%$ \\
\hline & & $45.50 \%$ & $10.0 \%$ & $50.08 \%$ \\
\hline \multirow{2}{*}{11} & \multirow{2}{*}{ UUS BPD KalTim } & $35.50 \%$ & $5.0 \%$ & $50.81 \%$ \\
\hline & & $42.00 \%$ & $10.0 \%$ & $50.94 \%$ \\
\hline \multirow{2}{*}{12} & \multirow{2}{*}{ UUS BPD NTB } & $37.00 \%$ & $5.0 \%$ & $50.25 \%$ \\
\hline & & $43.50 \%$ & $10.0 \%$ & $50.19 \%$ \\
\hline \multirow{2}{*}{13} & \multirow{2}{*}{ UUS BPD SulSelBar } & $47.50 \%$ & $5.0 \%$ & $50.80 \%$ \\
\hline & & $54.50 \%$ & $10.0 \%$ & $50.74 \%$ \\
\hline
\end{tabular}

Johnson, et.al (1994); Hite and Owers (1984) stated that one of the factors that determine the success of spin-off is the size of the parent company. The larger the company, the better success of spin-off would be than the smaller company. 
Lindholm-Dahlstrand (2000) showed that the firm's size becomes one of the factors that influence the growth of the subsidiary as the result of the spin-off. If this matter associated with the process of Islamic business unit spin-off in Indonesia, then it would be a problem for Islamic business unit spin-off process owned by BPD where most of the BPDs have a small size.

If a conventional bank ultimately decides to execute spin-off to its Islamic business unit into Islamic bank whether it is before or after reaching the period of spin-off according to the constitution, then it must be prepared well. The preparation mentioned here is in addition to the technical development of spin-off, that is a setup for Islamic business unit performance. Klepper and Thompson (2010) stated that a company that has a better performance tends to have the performance of post-spinoff. Therefore, if conventional banks wish Islamic bank as the result of the spin-off to have better performance, then the performance when it was still Islamic business unit must also have good performance. This matter is intended so that when the Islamic business unit becomes Islamic bank, it would operate independently and no longer depend on its parent bank.

Generally, on Table 7, it can be classified as (i) Conventional parent banks that categorized in BUKU 3, parent banks' asset above IDR 30 trillion and Islamic business unit's asset above IDR 1 trillion. The strategy that can choose is: executing Islamic business unit spin-off into Islamic bank or detaching Islamic business unit to other Islamic banks. Islamic business units that included in this category are Bank of DKI and Bank of BPD Jawa Timur. (ii) Conventional parent banks that categorized in BUKU 2, parent banks' asset above IDR 10 trillion and Islamic business unit's asset above IDR 1 trillion. The strategy that can choose is: detaching Islamic business unit to other Islamic banks or degrading the status of Islamic business unit into BPRS. (iii) Conventional parent banks that categorized in BUKU 2, parent banks' asset $\leq$ IDR 15 trillion, UUS's asset below IDR 1 trillion. The strategy that can use is the full conversion of parent bank into Islamic bank or detaching Islamic business unit to other Islamic banks. Islamic business units that included in this category are Bank of BPD Yogyakarta, Bank of BPD Nusa Tenggara Barat (NTB), and Bank of BPD Sulawesi Selatan and Barat (Sulselbar).

Islamic business units that have decided to split must fully be based on business consideration and corporate strategy, and not because of political factors such as orientation to the position, etc. Islamic business unit spin-off process will add new operating costs for Islamic bank itself, the promotion that follows by facility increase, the opening of new branches, etc. This matter must be prepared well so that it does not interrupt the operation of the Islamic bank as the result of the spinoff itself. Islamic business unit spin-off must consider the performance of the Islamic 
business unit itself. Klepper and Thompson (2010) stated that corporation that has better performance would performance post-spin-off. Therefore, if conventional banks wish Islamic bank as the result of the spin-off to have better performance, then the performance when it was still Islamic business unit must also have good performance. This matter is intended so that sharia subsidiaries as the result of spinoff would operate independently and no longer depend on their parent banks.

Table 7. The Condition of Sharia Unit and Its Parents

\begin{tabular}{ccccc}
\hline No. & \multicolumn{1}{c}{ Banks } & Asset of Sharia Unit & Asset of Parents & Capital Tier of Parents \\
\hline 1 & BPD Sumut & $1,875,420$ & $27,332,497$ & $2,035,197$ \\
2 & BPD SumBar & $1,280,669$ & $21,253,856$ & $1,999,620$ \\
3 & BPD Sumsel \& Babel & $1,630,609$ & $19,038,125$ & $1,524,015$ \\
4 & BPD Riau \& Kepri & $1,072,962$ & $21,808,872$ & $1,951,125$ \\
5 & BPD Yogyakarta & 509,930 & $9,138,389$ & $1,191,546$ \\
6 & BPD DKI & $3,487,651$ & $37,630,880$ & $5,703,466$ \\
7 & BPD Jawa Timur & $1,322,418$ & $49,145,272$ & $5,157,342$ \\
8 & BPD Jawa Tengah & $1,381,973$ & $50,216,985$ & $4,540,211$ \\
9 & BPD KalBar & $1,249,728$ & $14,014,718$ & $1,768,131$ \\
10 & BPD KalSel & 597,333 & $12,504,481$ & $1,419,147$ \\
11 & BPD KalTim & $1,322,510$ & $23,310,303$ & $3,243,335$ \\
12 & BPD NTB & 513,557 & $8,132,935$ & $1,026,536$ \\
13 & BPD Sulselbar & 824,909 & $15,716,026$ & $1,718,829$ \\
\hline
\end{tabular}

Based on issues above, encouragements of spin-off performed by regulators is contrary with Indonesian Banking Architecture (API) that has been arranged especially if it refers to reaching pillar one. Since the way of attainment of pillar one is through: (i) new capital increase whether from the old shareholder or new investor; (ii) merger with another bank (or other several banks) to reach new minimum capital requirements; (iii) issuance of new shares or secondary offering at capital market; (iv) issuance of subordinated loan. This spin-off trend is considered different from a way that tends to lead to a merger. Moreover, it is contrary to the purpose to create a healthy domestic banking structure. With the spin-off encouragement happening currently, it would bring out many Islamic banks but with small capital, so it even causes weak local banking structure. 
Tubke (2004) said that there are several factors that influence in spin-off process. First, a factor that is related to business activity, this factor is related to the size of the company and differences in the corporate sector between the parent company and its subsidiary. Second, a factor that is related to organization and company management. Third, a factor that is related to connection and support. There are three patterns of relationship that can create between a parent corporation and a subsidiary that wish to execute spin-off which is market-relatedness. Fourth, transfer factor or diversion in the form of experience transfer from the parent company to its subsidiary. Fifth, a factor that is related to motivation. Sixth, a factor that is related to the good business environment in the form of the characteristics of the regional business climate or legal framework. Conventional parent bank must treat Islamic bank as the result of the spin-off as part of its group of activities and not as the competitor, so that either parent bank or its subsidiary may grow rapidly.

\section{Conclusion}

The forecasting by using ARIMA shown that there is no sharia unit owned by Regional Development Bank can achieve the $50 \%$ of the parent bank asset. According to the estimation, the highest forecasting is sharia unit belonging to Bank of Sumatera Barat by $15.03 \%$ in 2023. The lowest prediction is sharia unit owned by Bank of Sulawesi Selatan and Barat by $6.28 \%$ in 2023. Besides that, by using simulation shows that the largest growth rate to achieve $50 \%$ share asset is $37 \%$ per year (assumption the parent's bank growth rate is 5\% per year) and $43.38 \%$ per year (by assumption the parent's bank growth rate is $10 \%$ per year). On the other side, by using simulation shows that the largest growth rate to achieve $50 \%$ share deposit funds is $39.65 \%$ per year ( an assumption the parent's bank growth rate is 5\% per year). For the assumption, the parent's bank growth rate is $10 \%$ per year the growth rate is $46.38 \%$ per year.

From these result, implies that the spin-off criteria should evaluate because there are no sharia unit can be achieved the 50\% share asset in 2023 . The spin-off policy is only one activity that can be done by the regulator to accelerate the growth of Indonesian Islamic banking industry. Several strategies can be done either by the regulator or parent's bank to speed up the development of the Indonesian Islamic banking industry.

\section{References}

Al Arif, M.N.R. (2014). Spin-offs and Its Impact on Third Party Funds in Indonesian Islamic Banking Industry. Economic Journal of Emerging Markets, Vol. 6 (1): 50-55 
Al Arif, M.NR. (2015a). Keterkaitan Kebijakan Pemisahan Terhadap Tingkat Efisiensi Pada Industri Perbankan Syariah di Indonesia. Jurnal Keuangan dan Perbankan, Vol. 19 (2): 295-304

Al Arif, M.NR. (2015b). The Effect of Spin-off Policy on Financing Growth in Indonesian Islamic Banking Industry. Jurnal Al-Ulum, Vol. 15 (1): 173-184

Al Arif, M.N.R. (2015c). Impact of Spin-off Policy on The Asset Growth on Indonesian Islamic Banking Industry. Journal of Islamic Economics, Banking, and Finance, Vol. 11, No. 4: 41-52

Al Arif, M.N.R. (2016). Analisis Pemisahan Unit Usaha Syariah Menjadi Bank Umum Syariah: Kasus Pada Undang-undang No. 21 Tahun 2008. (Unpublished Dissertation). Depok: Universitas Indonesia.

Al Arif, M.N.R. \& I. Haribowo. (2016). Tipe Pemisahan dan Pengaruhnya Terhadap Laba Pada Bank Umum Syariah Hasil Pemisahan. Jurnal Keuangan dan Perbankan. Vol. 20 (3): 479-486.

Dewati, H.R. 2015. Pemilihan Metode Spin Off Unit Bisnis Syariah dengan Pendekatan Analisa Faktor (Studi PT BNI Syariah dan PT Bank Syariah BRI). (Tesis Tidak Dipublikasikan). Bogor: Institut Pertanian Bogor.

Hamid, A. (2015). The Impact of Spin-off Policy To The Profitability on Indonesian Islamic Banking Industry. Journal Al-Iqtishad: Jurnal Ilmu Ekonomi Syariah (Journal of Islamic Economics), Vol. 7 (1): 131-140.

Johnson, G, et.al. (1994). The Market Reaction to Voluntary Corporate Spin-Offs: Revisited. Quarterly Journal of Business and Economics. Vol. 33 (4): 44-57.

Kiswono, B. (2012). Spin Off Unit Usaha Syariah (UUS), Kendala dan Strategi Penyelesaiannya. Working Paper. Jakarta: Bank Indonesia

Klepper, S. \& P. Thompson. (2010). Disaggrements and Intra-Industry Spinoffs. International Journal of Industrial Organization, Vol. 28(5): 526-538.

Nasuha, A. (2012). Dampak Kebijakan Spin-off Terhadap Kinerja Bank Syariah. Journal Al-Iqtishad: Jurnal Ilmu Ekonomi Syariah (Journal of Islamic Economics), Vol. 4, No. 2: 241-258.

Rizqullah. (2013). Pemilihan Metode Spin-Off Unit Usaha Syariah Bank Umum Konvensional Menjadi Bank Umum Syariah di Indonesia. (Unpublished Dissertation). Jakarta: IEF Trisakti.

Siswantoro, D. (2014). Analysis of Islamic Bank’s Performance and Strategy After Spin-off as Islamic Full-fledged Scheme in Indonesia. International Conference on Accounting Studies 2014, ICAS, Kuala Lumpur Malaysia.

Tubke, A. (2004). Success Factors of Corporate Spin-Offs. New York: Springer. 